\title{
Faktor Prognosis Terjadinya Perdarahan Gastrointestinal dengan Demam Berdarah Dengue pada Dua Rumah Sakit Rujukan
}

\author{
Rinang Mariko, Sri Rezeki S Hadinegoro, Hindra Irawan Satari \\ Departemen Ilmu Kesehatan Anak Fakultas Kedokteran Universitas Indonesia/RS Cipto Mangunkusumo, \\ Jakarta
}

\begin{abstract}
Latar belakang. Infeksi virus dengue masih menjadi masalah kesehatan di Indonesia. Angka kematian akibat dengue syok sindrom (DSS) yang disertai dengan perdarahan gastrointestinal hebat dan ensefalopati masih tetap tinggi. Oleh sebab itu, perlu diketahui faktor prognosis terjadinya perdarahan gastrointestinal sehingga diharapkan dapat mengantisipasi dini kejadian perdarahan gastrointestinal pada anak demam berdarah dengue (DBD)

Tujuan. Mengetahui faktor prognosis perdarahan gastrointestinal pada pasien demam berdarah dengue anak.

Metode. Dilakukan penelitian cross sectional retrospektif di RSUP Dr. Cipto Mangunkusumo dan RSUP Dr. M Djamil dengan mengambil data rekam medik pasien DBD yang dirawat dari Januari 2010 sampai Juni 2011. Diukur parameter klinis (lamanya syok, hepatomegali) dan laboratoris (jumlah trombosit, hemokonsentrasi, pemanjangan sistem koagulasi) pada pasien DBD. Data dianalisis dengan program statistik SPSS versi 17.

Hasil. Didapatkan 228 pasien yang menderita DBD. Pasien dengan nilai hematokrit 40,7\% mempunyai sensitivitas $58,3 \%$ dan spesifisitas $59,8 \%$ untuk meramalkan terjadinya perdarahan gastrointestinal. Durasi anak yang mengalami renjatan $>1$ jam 45 menit mempunyai faktor prognosis untuk terjadinya perdarahan gastrointestinal 14,4 kali dibanding anak yang mengalami renjatan $\leq 1$ jam 45 menit dengan sensitivitas $57,1 \%$ dan spesifisitas $91,5 \%$.

Kesimpulan. Durasi renjatan dan hematokrit (hemokonsentrasi) merupakan faktor prognosis terjadinya perdarahan gastrointestinal pada pasien DBD Sari Pediatri 2014;15(6):361-8.
\end{abstract}

Kata kunci: DBD, faktor prognosis, perdarahan gastrointestinal, anak

\footnotetext{
Alamat korespondensi:

Dr. Rinang Mariko, Sp.A. RSUD Sungai Dareh. Jl. Lintas Sumatera KM I, Pulau Punjung, Dhamas Raya, SUMBAR. E-mail: rinang_mariko@ idai.or.id.
}

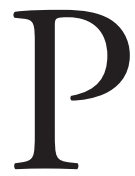

enyakit demam berdarah dengue (DBD) disebabkan virus dengue ditandai dengan gejala klinik yang khas berupa demam tinggi mendadak disertai manifestasi perdarahan dan bertendensi menimbulkan renjatan dan kematian. ${ }^{1}$ 
Sejak pertama kali ditemukan pada tahun 1968 hingga kini, infeksi virus dengue menunjukkan peningkatan insiden. Angka kesakitan penyakit DBD cenderung meningkat, walaupun angka kematian secara nasional cenderung turun. Angka penurunan tercatat $41,4 \%$, 4\%, 1,4\%, dan 0,9\% masing-masing pada tahun 1968, 1980, 2000, dan 2001. Data Kementrian Kesehatan menunjukkan bahwa pada tahun 2011 angka kesakitan DBD 22,9/100.000 penduduk dan angka kematian menurun menjadi $0,84 \%{ }^{3}$ Namun, angka kematian akibat dengue syok sindrom (DSS) yang disertai dengan perdarahan gastrointestinal hebat dan ensefalopati masih tetap tinggi. ${ }^{4}$ Perdarahan pada DBD disebabkan keadaan patologis pada trombosit, faktor pembekuan darah, dan pembuluh darah. Ketiga faktor ini saling memengaruhi dan faktor mana yang lebih berperan dalam menimbulkan perdarahan pada DBD sampai sekarang belum diketahui dengan tuntas. ${ }^{5}$

Manifestasi perdarahan yang selalu ada pada DBD biasanya ringan dan kebanyakan ditemukan ptekie kecil yang menyebar pada kulit dan kadang-kadang submukosa. Tes tourniquet positif menunjukkan adanya peningkatan permeabilitas kapiler dan merupakan temuan yang paling sering terjadi pada awal penyakit. Perdarahan gastrointestinal yang membutuhkan tranfusi darah cukup banyak terjadi dan biasanya terjadi setelah renjatan. Perdarahan gastrointestinal dalam bentuk hematemesis dan/ atau melena merupakan gejala perdarahan berat yang sering dijumpai. Keadaan tersebut dapat menyebabkan kematian akibat terjadi renjatan yang lama disertai perdarahan yang masif/berat, dapat dijumpai pula perdarahan pada di berbagai organ lainnya, seperti jantung, paru-paru, hepar, dan otak. ${ }^{3}$ Penyebab perdarahan pada DBD sangat komplek dan mungkin melibatkan satu atau lebih dari trombositopenia, kerusakan pembuluh darah kecil, gangguan fungsi trombosit dan koagulopati yang menyebabkan koagulasi intravaskular diseminata. ${ }^{6}$ Penelitian Lum $\mathrm{dkk}^{7}$ mengatakan bahwa syok yang berkepanjangan merupakan faktor prognosis terjadinya perdarahan hebat, sedangkan trombositopenia dan pemanjangan koagulasi tidak menjadi penyebab terhadap terjadinya perdarahan hebat.

Gangguan hemostasis pada DBD tampaknya multifaktorial yang melibatkan vaskulopati, trombositopeni, gangguan fungsi trombosit, dan koagulopati. Sebagian besar hasil penelitian melaporkan bahwa mekanisme perdarahan pada DBD merupakan kejadian pemakaian koagulopati. Temuan mengenai perubahan ringan pada fungsi hepar dan prothrombin time yang normal atau sedikit memanjang pada kasus ini mendukung peran pemakaian sistem koagulopati. Disseminated Intravascular Coagulation (DIC) yang terjadi pada renjatan yang berkepanjangan dan berat dengan asidosis yang sulit diatasi dan peningkatan transaminase hepar yang nyata dapat terjadi perdarahan yang hebat dengan prognosis yang buruk. ${ }^{5,8}$ Secara potensial, DIC dapat terjadi juga pada DBD tanpa syok. Pada masa dini DBD, peran DIC tidak menonjol dibandingkan dengan perubahan plasma, tetapi apabila penyakit memburuk sehingga terjadi syok dan asidosis maka syok akan memperberat DIC sehingga perannya akan mencolok. Syok dan DIC akan saling memengaruhi sehingga penyakit akan memasuki syok ireversibel disertai perdarahan hebat, terlibatnya organ-organ vital yang biasanya diakhiri dengan kematian.

\section{Metode}

Penelitian cross sectional retrospektif yang mengukur parameter klinis (lamanya syok, hepatomegali) dan laboratoris (jumlah trombosit, hemokonsentrasi, pemanjangan sistem koagulasi) pada pasien DBD. Data diambil dari data sekunder rekam medik pasien yang dirawat dari Januari 2010 sampai Juni 2011 di Departemen Ilmu Kesehatan Anak RSUP Dr. Cipto Mangunkusumo Jakarta dan RSUP Dr M Djamil Padang. Populasi target adalah pasien anak berumur 1 bulan - 18 tahun dengan diagnosis DBD/DSS pada saat masuk rumah sakit. Populasi terjangkau adalah pasien yang dirawat di bangsal infeksi/ruang intensif anak RSUP Dr. Cipto Mangunkusumo dan RSUP Dr. M Djamil dengan diagnosis DBD berdasarkan kriteria WHO 1997 pada tahun 2010-2011 dengan pemeriksaan serologi IgG dan IgM dengue positif. Kriteria eksklusi adalah rekam medis pasien hilang/ tidak lengkap.

\section{Hasil}

Karakteristik sampel berdasarkan usia termuda 6 bulan dan tertua 16 tahun dengan rerata umur pasien 8,5 tahun. Berdasarkan jenis kelamin terdapat 112 anak laki-laki dan 116 perempuan. Anak usia $\leq 8,5$ 
tahun mempunyai faktor prognosis untuk terjadinya perdarahan gastrointestinal 2,9 kali dibandingkan dengan anak usia $>8,5$ tahun. Anak laki-laki memiliki faktor prognosis perdarahan gastrointestinal 1,8 kali dibandingkan dengan perempuan, tetapi secara statistik perbedaan tersebut tidak bermakna ( $p>0,05)$.

Berdasarkan Gambar 1 diperoleh hasil bahwa pada nilai hematokrit 40,7\% mempunyai sensitivitas 58,3\% dan spesifisitas $59,8 \%$ untuk meramalkan terjadinya perdarahan gastrointestinal.
Tidak terdapat perbedaan bermakna untuk nilai hematokrit pada perdarahan gastrointestinal dan perdarahan ringan $(\mathrm{p}=0,089)$. Nilai hematokrit $>40,7 \%$ bukan faktor prognosis terjadinya perdarahan masif. Interval kepercayaan yang mencakup angka 1 menunjukkan bahwa nilai hematokrit $>40,7 \%$ tidak konklusif sebagai faktor prognosis terjadinya perdarahan gastrointestinal. Gambar 2 menunjukkan bahwa jumlah trombosit terendah kurang dari atau sama dengan $49.500 / \mathrm{mm}^{3}$ mempunyai sensitivitas

Tabel 1. Umur pada perdarahan gastrointestinal dan perdarahan ringan

\begin{tabular}{|c|c|c|c|c|c|c|c|c|}
\hline & \multicolumn{2}{|c|}{$\begin{array}{l}\text { Perdarahan } \\
\text { gastrointestinal }\end{array}$} & \multicolumn{2}{|c|}{ Perdarahan ringan } & \multirow{2}{*}{$\begin{array}{c}\text { Total } \\
\mathrm{N}\end{array}$} & \multirow[t]{2}{*}{$\mathrm{p}$} & \multirow[t]{2}{*}{ OR } & \multirow[t]{2}{*}{ IK 95\% } \\
\hline & $\mathrm{N}$ & (\%) & $\mathrm{N}$ & (\%) & & & & \\
\hline \multicolumn{9}{|l|}{ Umur (tahun) } \\
\hline$\leq 8,5$ & 18 & 14,9 & 103 & 85,1 & 121 & 0,023 & 2,9 & $1,122-7,713$ \\
\hline$>8,5$ & 6 & 5,6 & 101 & 94,4 & 107 & & & \\
\hline Total & 24 & & 204 & & 228 & & & \\
\hline \multicolumn{9}{|l|}{ Jenis kelamin } \\
\hline Laki-laki & 15 & 13,4 & 97 & 86,6 & 112 & 0,166 & 1,838 & $0,770-4,392$ \\
\hline Perempuan & 9 & 7,8 & 107 & 92,2 & 116 & & & \\
\hline Total & 24 & & 204 & & 228 & & & \\
\hline \multicolumn{9}{|l|}{ Nilai hematokrit (\%) } \\
\hline$>40,7$ & 10 & 7,6 & 122 & 92.4 & 132 & 0,089 & 0,480 & $0,203-1,133$ \\
\hline$\leq 40,7$ & 14 & 14,6 & 82 & 85,4 & 96 & & & \\
\hline Total & 24 & & 204 & & 228 & & & \\
\hline \multicolumn{9}{|l|}{$\begin{array}{l}\text { Trombosit terendah (/ } \\
\left.\mathrm{mm}^{3}\right)\end{array}$} \\
\hline$\leq 49.500$ & 15 & 17 & 73 & 83 & 88 & 0,011 & 2,991 & $1,247-7,172$ \\
\hline$>49.500$ & 9 & 6,4 & 131 & 93,6 & 140 & & & \\
\hline Total & 24 & & 204 & & 228 & & & \\
\hline \multicolumn{9}{|l|}{ Durasi renjatan } \\
\hline$>1$ jam 45 menit & 8 & 61,5 & 5 & 38,5 & 13 & 0,00 & 14,4 & $3,551-58,392$ \\
\hline$\leq 1$ jam 45 menit & 6 & 10 & 54 & 90 & 60 & & & \\
\hline Total & 14 & & 59 & & 73 & & & \\
\hline \multicolumn{9}{|l|}{ Nilai PPT (detik) } \\
\hline$>12,4$ & 1 & 16,7 & 5 & 83,3 & 6 & 0,612 & 0,500 & $0,034-7,452$ \\
\hline$\leq 12,4$ & 2 & 28,6 & 5 & 71,4 & 7 & & & \\
\hline Total & 4 & & 10 & & 13 & & & \\
\hline \multicolumn{9}{|l|}{ Nilai APTT (detik) } \\
\hline$>59,5$ & 4 & 66,7 & 2 & 33,3 & 6 & 0,015 & & \\
\hline$\leq 59,5$ & 0 & 0 & 8 & 100 & 8 & & & \\
\hline Total & 4 & & 10 & & 14 & & & \\
\hline \multicolumn{9}{|l|}{ Hepatomegali } \\
\hline Hepatomegali & 10 & 11,1 & 80 & 88,9 & 90 & 0,816 & 1,107 & $0,469-2,613$ \\
\hline Tidak hepatomegali & 14 & 10,1 & 124 & 89,9 & 138 & & & \\
\hline Total & 24 & & 204 & & 228 & & & \\
\hline
\end{tabular}




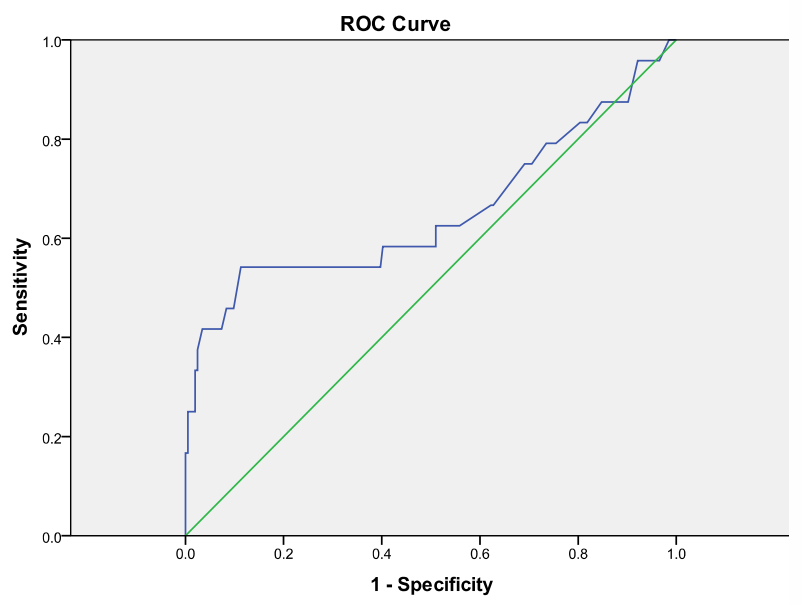

Diagonal segments are produced by ties.

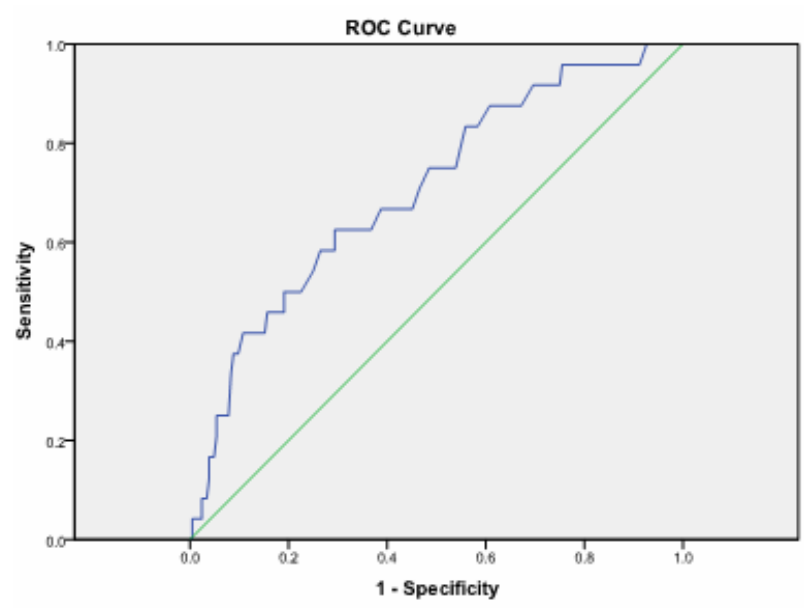

Diagonal segments are produced by ties.

Gambar 1 dan 2. Analisis ROC nilai hematokrit dan trombosit terendah pada perdarahan gastrointestinal

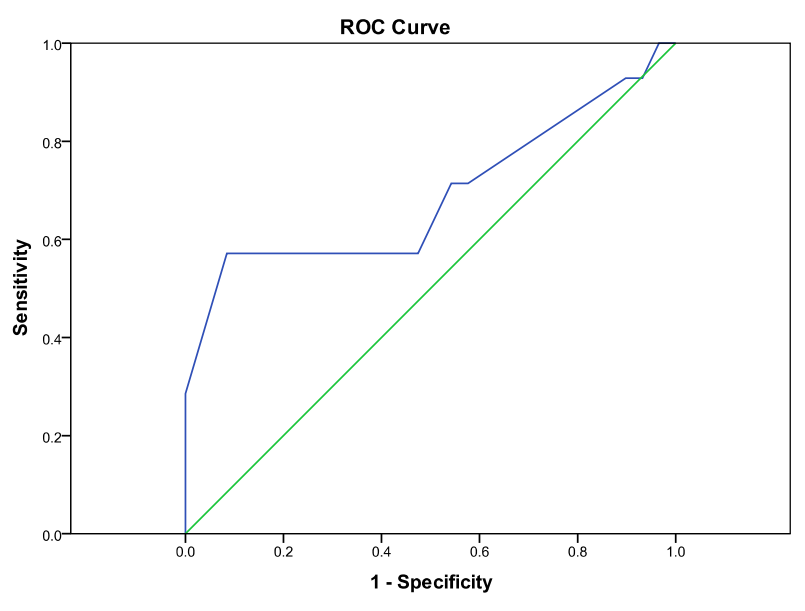

Diagonal segments are produced by ties.

Gambar 3. Analisis ROC durasi renjatan pada perdarahan gastrointestinal

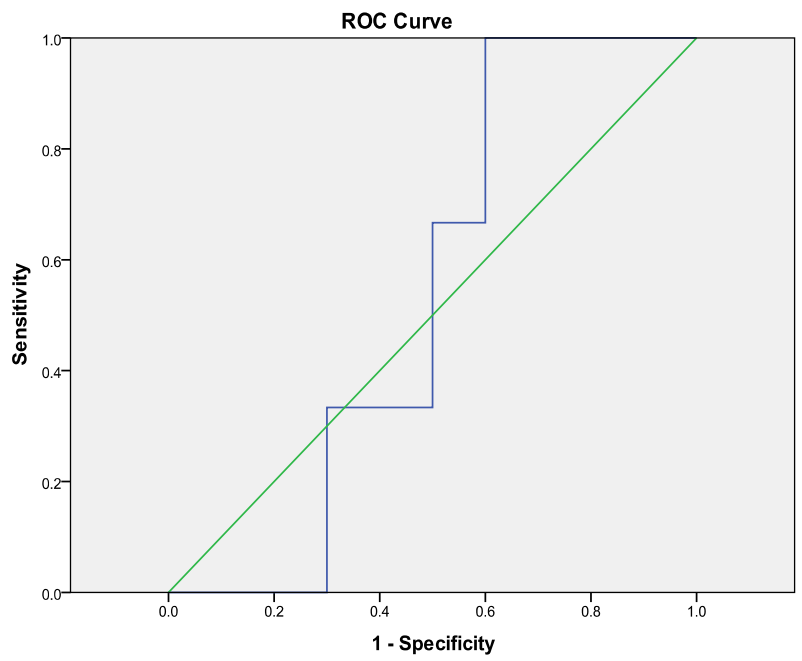

Gambar 4. Analisis ROC nilai PPT

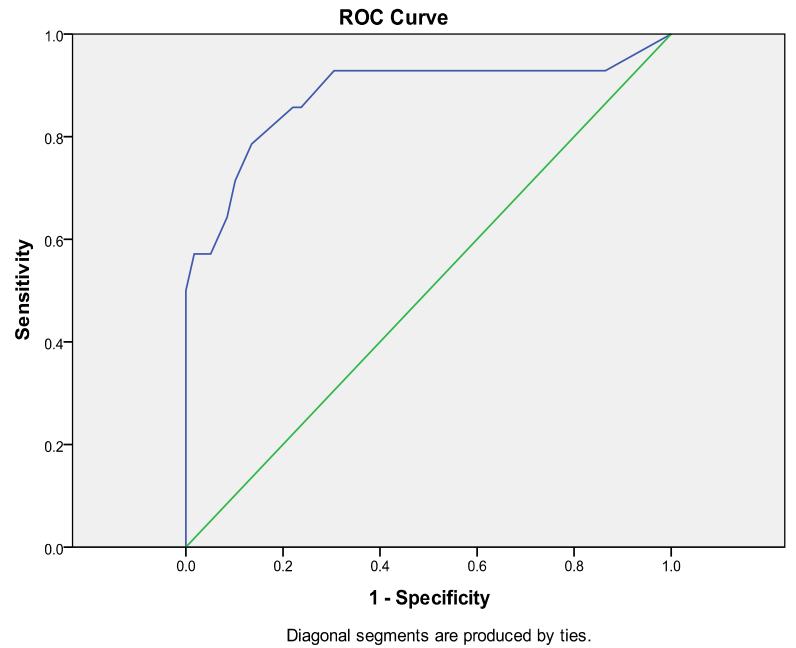

Gambar 5. Analisis regresi logistik multivariat

$62,5 \%$ dan spesifisitas $64,5 \%$ untuk meramalkan terjadinya perdarahan gastrointestinal.

Nilai trombosit $\leq 49.500 / \mathrm{mm}^{3}$ mempunyai faktor prognosis terjadinya perdarahan gastrointestinal 2,99 kali dibandingkan apabila jumlah trombosit $>49.500$ / $\mathrm{mm}^{3}$. Gambar 3 menunjukkan bahwa lamanya renjatan lebih dari 1 jam 45 menit mempunyai sensitivitas $57,1 \%$ dan spesifisitas $91,5 \%$ untuk meramalkan terjadinya perdarahan gastrointestinal. Anak yang mengalami renjatan $>1$ jam 45 menit mempunyai faktor prognosis perdarahan gastrointestinal 14,4 kali dibanding anak yang mengalami renjatan $\leq 1$ jam 45 menit. Interval kepercayaan tidak mencakup angka 1 , artinya durasi renjatan $>1$ jam 45 menit merupakan faktor prognosis tetapi mempunyai rentang yang cukup lebar. 
Gambar 4 memperlihatkan bahwa nilai PPT lebih dari 12,4 detik mempunyai sensitivitas $66,7 \%$ dan spesifisitas $50 \%$ untuk meramalkan terjadinya perdarahan gastrointestinal.

Nilai OR kurang dari 1 dan IK95\% mencakup angka 1 yang berarti nilai PPT bukan merupakan faktor prognosis untuk terjadinya perdarahan gastrointestinal. Terdapat perbedaan bermakna $(\mathrm{p}=0,015)$ nilai APTT pada perdarahan gastrointestinal dan ringan. Namun, nilai APTT lebih dari 59,5 detik tidak dapat meramalkan terjadinya perdarahan gastrointestinal (OR tidak dapat dihitung karena ada sel yang bernilai 0). Diperoleh pasien yang tidak hepatomegali terdapat 14 pasien menderita perdarahan gastrointestinal berat, sedangkan yang hepatomegali terdapat 10 pasien yang mengalami perdarahan gastrointestinal berat. Hasil analisis regresi logistik multivariat bahwa hematokrit dan lama renjatan merupakan faktor prognosis utama untuk terjadinya perdarahan gastrointestinal, dengan nilai AUC 88,1\%.
Wichman dkk, ${ }^{9}$ di Thailand, didapatkan infeksi dengue berat lebih banyak pada orang dewasa dibanding anak. Walaupun secara statistik tidak bermakna, hal tersebut berhubungan dengan infeksi dengue kedua lebih yang sering terjadi pada orang dewasa dibanding anak dan keparahan infeksi dengue lebih sering terjadi pada infeksi kedua. Penelitian Nguyen dkk, ${ }^{10}$ di Vietnam, didapatkan frekuensi dan kejadian DSS lebih sering pada anak usia 6-10 tahun, tetapi anak usia 1-5 tahun mempunyai risiko lebih tinggi mengalami kematian dibanding anak yang lebih tua.

Penelitian Sudjaritruk dkk, ${ }^{11}$ di Chiang Mai, didapatkan umur terbanyak yang terinfeksi dengue 11-15 tahun, tetapi penelitian tersebut tidak menghubungkan umur dengan berat ringannya perdarahan. Hal ini dihubungkan dengan perubahan tempat transmisi virus dengue terjadi, yaitu dari rumah ke sekolah dan efektifnya program pemberantasan nyamuk di rumah. Penelitian Hammond $\mathrm{dkk},{ }^{12} \mathrm{di}$

Tabel 2. Analisis regresi logistik multivariat

\begin{tabular}{lccccc}
\hline Variabel/Faktor Prognosis & Odds Ratio & $\mathrm{p}$ value & \multicolumn{3}{c}{ IK 95\% } \\
\hline Umur & 1,257 & 0,786 & 0,242 & - & 6,540 \\
Jenis kelamin & 0,215 & 0,076 & 0,039 & - & 1,175 \\
Trombosit & 0,260 & 0,260 & 0,041 & - & 1,645 \\
Hematokrit & 12,561 & 0,007 & 2,006 & - & 78,654 \\
Lama renjatan & 0,047 & 0,047 & 0,007 & - & 0,329 \\
\hline
\end{tabular}

\section{Pembahasan}

Kami menemukan bahwa anak usia $\leq 8,5$ tahun mempunyai faktor prognosis untuk terjadinya perdarahan gastrointestinal 2,9 kali dibandingkan dengan anak usia $>8,5$ tahun. Interval kepercayaan yang mencakup angka 1 menunjukkan bahwa usia tidak konklusif sebagai faktor prognosis terjadinya perdarahan gastrointestinal, tetapi segmen yang terletak di atas nilai 2 cukup besar sehingga menimbulkan dugaan bahwa banyak di antara anak usia $\leq 8,5$ tahun mempunyai faktor prognosis terjadinya perdarahan gastrointestinal.

Usia adalah salah satu faktor yang memengaruhi kepekaan terhadap infeksi virus dengue. Semua usia dapat diserang, meskipun baru beberapa hari setelah lahir. Pada pengalaman pertama epidemik di Bangkok, anak usia muda terbukti yang banyak mengalami kasus dengue berat. Di Indonesia, anak yang terkena DBD/SSD berkisar usia 5-9 tahun. ${ }^{8}$ Pada penelitian
Nicaragua, dilaporkan kejadian perdarahan internal meningkat sesuai dengan peningkatan umur, yaitu 6,3\% pada bayi, 9,4\% pada anak, dan $15,2 \%$ pada dewasa.

Kami tidak mendapatkan hubungan antara jenis kelamin dengan tingkat perdarahan infeksi dengue. Hal tersebut sesuai dengan penelitian Nguyen $\mathrm{dkk}^{10}$ pada bayi terinfeksi dengue yang tidak terdapat hubungan antara jenis kelamin dengan tingkat keparahan infeksi dengue. Hasil penelitian Nguyen dkk ini juga memperlihatkan bahwa tidak ada hubungan antara jenis kelamin dengan komplikasi demam berdarah dengue berat, seperti syok berulang, perdarahan gastrointestinal, kegagalan pernafasan, dan ensefalopati pada bayi. Hal ini bisa dijelaskan bahwa produksi sitokin dan antibodi terhadap virus dengue tidak berbeda antara bayi laki-laki dan perempuan.

Peningkatan nilai hematokrit merupakan manifestasi hemokonsentrasi yang terjadi akibat kebocoran plasma ke ruang ekstravaskular melalui kapiler yang 
rusak. Akibat kebocoran ini volume plasma menjadi berkurang yang dapat mengakibatkan terjadinya syok hipovolemik dan kegagalan sirkulasi. Hasil penelitian ini tidak mendukung penelitian Setiati dkk, ${ }^{13}$ yang mendapatkan nilai hematokrit $>42 \%$ merupakan faktor risiko untuk terjadinya renjatan dan perdarahan pada pasien DBD.

Penyebab trombositopenia pada DBD masih kontroversial. Trombositopenia terjadi akibat supresi sumsum tulang, destruksi, dan pemendekan masa hidup trombosit. Ditemukannya kompleks imun pada permukaan trombosit yang mengeluarkan ADP (adenosin diposphat) diduga sebagai penyebab agregasi trombosit yang kemudian dimusnahkan oleh sistem retikuloendotelial, khususnya limpa dan hati. Agregasi trombosit ini akan menyebabkan pengeluaran PF3 yang mengakibatkan terjadinya koagulopati konsumtif, perdarahan, dan DIC.

Hasil penelitian kami sesuai dengan penelitian Narayanan $\mathrm{dkk}^{14}$ yang mendapatkan jumlah trombosit terendah $<50.000 / \mathrm{mm}^{3}$ merupakan faktor risiko terjadinya perdarahan. Shivbalan $\mathrm{dkk}^{15}$ menyatakan jumlah trombosit $<50.000 / \mathrm{mm}^{3}$ merupakan faktor prediktor untuk terjadinya perdarahan spontan. Wichmann $\mathrm{dkk}^{9}$ dalam penelitiannya juga menyimpulkan bahwa terdapat perbedaan antara penurunan kadar trombosit pada DBD dengan perdarahan ringan dan perdarahan masif.

Hasil penelitian kami tidak mendukung pernyataan Mourao dkk ${ }^{16}$ di Brazilia bahwa jumlah trombosit saat masuk atau jumlah trombosit terendah yang tercatat tidak berkorelasi dengan klinis perdarahan. Menurut Mourao perdarahan berat pada DBD/DSS tidak hanya disebabkan oleh trombositopenia $\left(<50 \times 10^{\%} / \mathrm{L}\right)$, tetapi perdarahan berat dapat disebabkan oleh gangguan fungsi trombosit dan mungkin peningkatan replikasi virus dengue. Lum $\mathrm{dkk}^{7}$ juga mendapatkan bahwa jumlah trombosit terendah bukan merupakan faktor risiko terjadinya perdarahan masif pada DBD.

Renjatan menimbulkan gangguan perfusi dan pasokan oksigen ke jaringan yang mengakibatkan hipoksia dan jejas selular. Jejas selular yang terjadi akan menginduksi produksi dan pelepasan mediator inflamasi serta memacu terjadinya DIC dan berakhir pada perdarahan masif. Kerusakan sel akan menjadi lebih berat dengan teraktivasinya sistem komplemen melalui jalur klasik dan alternatif, selanjutnya memicu pembentukan anafilatoksin C3a dan C5a. Selain itu, juga terjadi aktivasi kaskade koagulasi, menyebabkan trombosis mikrovaskular, dengan fibrinolisis, dan episode iskemik berulang. Renjatan yang lama atau tidak teratasi merupakan prognosis yang buruk bagi pasien.

Hasil penelitian kami sama dengan penelitian Thanh Phuong $\mathrm{dkk}^{17}$ yang menyebutkan terdapat perbedaan terjadinya perdarahan masif pada pasien yang mengalami syok tidak teratasi atau prolonged syok dengan tidak mengalami syok. Penelitian ini mendukung penelitian yang dilakukan oleh Lum $\mathrm{dkk}^{7}$ yang menyebutkan bahwa durasi renjatan sebagai faktor prognosis terjadinya perdarahan masif. Hal senada dikatakan Gatot $\mathrm{dkk}^{18}$ bahwa renjatan yang berkepanjangan disertai asidosis dapat mencetuskan perdarahan hebat.

Pemanjangan APTT pada infeksi virus dengue dapat terjadi akibat penurunan kadar faktor pembekuan II, V, VII, VIII, IX, dan X serta kadar fibrinogen. Sistem koagulasi disusun oleh faktor koagulasi yang merupakan protein inaktif yang beredar dalam darah. Pembentukan kompleks virus dengue dengan antibodi atau mediator sistem fagosit yang teraktivasi akibat infeksi virus dapat mengaktifkan sistem koagulasi. Penurunan faktor koagulasi tersebut disebabkan terjadinya consumption coagulopathy yang teraktivasi oleh fagosit mononuklear dan pelepasan platelet factor 3 (PF3) yang berasal dari agregasi trombosit, defisiensi kompleks protrombin akibat kerusakan hati.'

Hasil penelitian kami sama dengan penelitian Almas dkk ${ }^{19}$ yang mendapatkan perbedaan APTT pada perdarahan gastrointestinal dan ringan. Penelitian ini juga mendukung penelitian Budastra $\mathrm{dkk}^{20}$ yang menyebutkan terdapat hubungan yang bermakna antara peningkatan nilai APTT dengan perdarahan gastrointestinal. Berbeda dengan hasil penelitian Lum $\mathrm{dkk}^{7}$ yang mendapatkan bahwa pemanjangan waktu protrombin bukan merupakan faktor prognosis perdarahan.

Pada penelitian kami, tidak didapatkan hubungan antara pembesaran hati dengan tingkat perdarahan pada pasien. Wichman $\mathrm{dkk}^{9}$ mendapatkan bahwa pembesaran hati berhubungan dengan kejadian perdarahan, 45\% dari pasiennya mengalami perdarahan gastrointestinal. Penelitian Sudjaritruk dkk ${ }^{11}$ menyebutkan hepatomegali lebih banyak pada anak yang menderita dengue shock syndrome.

Analisis regresi logistik mulitivariat dilakukan pada variabel dengan $p<0,25$ dan jumlah sampel mencukupi, yaitu variabel umur, jenis kelamin, trombosit, nilai hematokrit dan lama renjatan. Hasil analisis regresi logistik multivariat didapatkan hematokrit dan lama 
renjatan merupakan faktor prognosis utama untuk terjadinya perdarahan gastrointestinal, dengan nilai AUC 88,1\%.

\section{Kesimpulan}

Disimpulkan bahwa durasi renjatan, dan hematokrit (hemokonsentrasi) merupakan faktor prognosis terjadinya perdarahan gastrointestinal pada pasien DBD, sedangkan usia, jenis kelamin, trombosit terendah, pemanjangan koagulasi dan hepatomegali tidak terbukti secara statistik dan tidak konklusif secara klinis sebagai faktor prognosis perdarahan gastrointestinal pada pasien DBD.

\section{Daftar pustaka}

1. Sutaryo. Perkembangan patogenesis demam berdarah dengue. Dalam: Hadinegoro SRH, Satari HI, penyunting. Demam berdarah dengue. Naskah lengkap pelatihan bagi pelatih dokter spesialis anak dan dokter spesialis penyakit dalam dalam tatalaksana kasus DBD. Jakarta: Balai Penerbit Fakultas Kedokteran Universitas Indonesia;2005. h.32-43.

2. Karyanti MR, Hadinegoro SR. Perubahan epidemiologi demam berdarah dengue di Indonesia. Sari Pediatri 2009; 10:424-32.

3. Subdirektorat Pengendalian Arbovirus. Informasi umum demam berdarah dengue. Jakarta: Dit PPBB Ditjen PP dan PL KemKes RI; 2011.

4. Sumarmo PS. Infeksi virus dengue. Dalam: Sumarmo PS, Garna H, Hadinegoro SRH, penyunting. Buku ajar ilmu kesehatan anak dan penyakit tropis. Edisi pertama. Jakarta: Balai Penerbit Fakultas kedokteran Universitas Indonesia;2002.h.176-208.

5. Nimmannitya $S$. Dengue hemarrhagic fever: diagnosis and management. Dalam: D.J Gubler, G Kuno, penyunting. Dengue and Dengue Haemorrhagic Fever. Cambridge: Cab International:The UK at the university Press; 1997.h.133-45.

6. Harikushartono. Demam berdarah dengue. Dalam: Soegeng Soegijanto, penyunting. Ilmu penyakit anak diagnosis dan penatalaksanaan. Jakarta: Penerbit Salemba Medika; 2002.h.46-67.

7. Lum LCS, Gob AYT, Chan PWK, Amin AL, Lam SK. Risk factors for haemorrhage in severe dengue infections.J Pediatr 2002;140:629-31.
8. Tumbelaka AR. Diagnosis demam dengue/demam berdarah dengue. Dalam: Hadinegoro SRH, Satari HI, penyunting. Demam berdarah dengue naskah lengkap pelatihan bagi pelatihan dokter spesialis anak dan dokter spesialis penyakit dalam. Tatalaksana demam berdarah dengue. Jakarta: FKUI; 2000.h.73-9.

9. Wichmann O, Hongsirin S, Bowonwatanuwonge, Chotivanich K, Sukthana Y, Pukrittayakamce S. Risk factors and clinical features associated with severe dengue infection in adults and childrren during the 2001 epidemic in Chonburi, Thailand. Trop Med and Inter Health 2004;9:1022-9.

10. Hung NT, Lan NT, Lei HY, Lin YS, Lien LB, Huang KJ. Association between sex, nutritional status, severity of dengue hemorrhagic fever and immune status in infants with dengue hemorrahagie fever. Am J Trop. Med. Hug 2005;72:370-4.

11. Sudjaritruk T, Oberdorfer P. Clinical characteristics and outcomes of dengue-infected children admitted to the Chiang Mai University Hospital during an outbreak in 2008. Chiang Mai Med J 2011;50:95-104.

12. Hammond SN, Balmaseda A, Perez L, Tellez Y, Saborio SI, Mercado JC, dkk. Differences in dengue severity in infants, children, and adults in a 3-year hospital-based study in Nicaragua. Am J Trop Med Hyg 2005;73:106370 .

13. Setiati TE, Mairuhu ATA, Koraka P, Supriatna M, Gillavry MRM, Brandjes DPM, dkk. Dengue disease severity in Indonesian children: an evaluation of the World Health Organization classification system. BMC Infect Dis 2007;7:1-8.

14. Narayanan M, Aravind MA, Prema R, Jeyapaul MP. Dengue fever clinical and laboratory parameters associated with complications. Dengue Bulletin 2003;27:108-15.

15. Shivbalan, Anandnathan K, Balasubramanian, Manjula D, Amairaj E. Predictor of spontaneous bleeding in dengue. Indian J Pediatr 2004;71:33-5.

16. Mourao MPG, Lacerda MVG, Macedo VO, Santos JB. Thrombocytopenia in patients with dengue virus infection in the Brazilian Amazon. Platelets 2007;18:605-12.

17. Phuong CXT, Nhan NT, Kneen R, Thuy PTT, Thien CV, Nga NTT, dkk. Clinical diagnosis and assessment of severity of confirmed dengue infection in Vietnamese children :is the world health organization classification system helpful? Am J.Trop Med Hyg,2004:70:72-9.

18. Gatot D. Perubahan hematologi pada infeksi dengue. Dalam: Hadinegoro SRH, Satari HI, penyunting 
Demam berdarah dengue naskah lengkap pelatihan bagi dokter spesialis anak dan dokter spesialis penyakit dalam tatalaksana demam berdarah dengue. Jakarta: FKUI;2000.h.44-54.

19. Almas A, Parkash O, Akhter J. Clinical factors associoated with mortality in dengue infection at a tertiary care center. Southeast Asian J Trop Med Public Health 2010;40:333-40.

20. Budastra IN, Arhana BNP, Mudita IB. Plasma prothrombin time and activated partial thromboplastin time as predictors of bleeding manifestations during dengue hemorrhagic fever. Paediatr Indones 2009;49:69-74. 